\title{
How Good is Your Estuarine Water?
}

\author{
Sufia Zaman ${ }^{1}$ and Abhijit Mitra ${ }^{2 *}$ \\ ${ }^{1}$ Department of Oceanography, Techno India University, India \\ ${ }^{2}$ Department of Marine Science, University of Calcutta, India
}

Received: July 01, 2017; Published: July 10, 2017

*Corresponding author: Abhijit Mitra, Department of Marine Science, University of Calcutta, 35 B.C. Road, Kolkata 700019, India, Tel: 9831269550;

Email: abhijit_mitra@hotmail.com

\begin{abstract}
The coastal and estuarine zone of West Bengal is noted for its rich biodiversity owing to the presence of Sundarbans mangrove ecosystem. However, due to intense industrialization and urbanization, many of the pockets have become ecologically sensitive. The present paper is an attempt to evaluate the Ecologically Sensitive Zone (ESZ) through enumeration of Aquatic Health Index (AHI). In the present programme, three stations in and around Indian Sundarbans namely Canning, Junput and Sagar Island were selected and the aquatic health index value of these stations varied as per the order Sagar Island > Canning > Junput. The lower value of the index reflects deteriorated condition of the coastal water due to excessive industrial, agricultural and domestic run-off. The high values of the index are the indicators of congenial coastal environment.
\end{abstract}

\section{Introduction}

India, with a long coastline of over $8000 \mathrm{~km}$ and 2 million sq. $\mathrm{km}$ of EEZ, has great potential for utilizing the marine and estuarine resources for the economic benefit of the country. West Bengal, a maritime state of the northeastern part of the country, adjacent to Bangladesh, is indented in the south by numerous river openings. The state has a coastal area of 10,055 sq. km spread in three major districts namely 24 Parganas (N), 24 Parganas (S) and Midnapur (E). The Hugli-Matla estuarine complex adjacent to coastal West Bengal is one of the most dynamic estuaries of the world, which is serving as the nursery of several varieties of finfishes and shellfishes that have great potentiality in strengthening the economic backbone of the country. However, it has become a significant conveyor of pollutants of different categories as because this system receives domestic, agricultural and industrial wastes containing cellulose, acids, alkalis, nitrogenous compounds, heavy metals, fly ash, phenol, sulphides and pesticide residues, which adversely affect the fish food organisms, near the outfall regions (Mitra, 1998). Matla and other eastward estuaries receive Kolkata and suburban sewage with organic load, heavy metals, ammonia and synthetic detergents flowing down through the Kulti and Bidyadhari estuaries (www. annauniv.edu/ion/info). The chain of the industries situated in and around Haldia port-cum-industrial complex has aggravated the situation in the western sector of Indian Sundarbans. Regular monitoring of the entire process is of utmost importance in this context to keep an eagle's eye on the quality of aquatic phase in and around Indian Sundarbans.

One important step towards this is scaling of the water quality of different site through consideration of most relevant parameters, which are functions of space and time. The process of scaling is done by developing an index through which a single value can be assigned to the aquatic phase for the purpose of its scoring in terms of status, use and management. Thus AHI aims at giving a single value to a particular aquatic system on the basis of list of constituents (parameters/variables) and their concentrations in the said aquatic system. One can then compare different samples for quality on the basis of the index value of each sample. The present article is an approach to compare the AHI of three sites in different salinity zones in and around Indian Sundarbans, with the aim to prepare a scorecard for rating these water bodies in connection to the ecologically sensitive zone.

\section{Materials and Methods}

The entire network of the present programme consists of the evaluation of the health of coastal and estuarine water with respect to selective physico-chemical variables like surface water salinity, $\mathrm{pH}$, temperature, transparency, dissolved oxygen (DO), nitrate, phosphate, silicate, oil and grease, dissolved $\mathrm{Pb}$, dissolved $\mathrm{Zn}$ and dissolved $\mathrm{Cu}$ during June, 2016. Samplings have been carried out at three stations in and around Indian Sundarbans namely Canning (low saline zone), Junput (high saline zone) and Sagar Island (high saline zone).

For convenience, the entire working procedure has been divided into three phases as mentioned below:

\section{Phase A: Site Selection.}

II. Phase B: Analysis of hydrological parameters of water bodies. 
III. Phase C: Evaluation of water quality index.

\section{Phase A: Site Selection}

Samplings were carried out from three stations in and around Indian Sundarbans namely Canning (Stn. 1), Junput (Stn. 2) and Sagar Island (Stn. 3) during premonsoon season (June, 2016).

\section{Phase B: Analysis of hydrological parameters of pond} water

The relevant hydrological parameters in connection to identification of ecologically sensitive zone in the coastal stretch of West Bengal and associated estuaries are surface water salinity, fecal coliform, BOD, dissolved oxygen (DO), oil and grease, dissolved $\mathrm{Pb}$, dissolved $\mathrm{Zn}$, dissolved $\mathrm{Cu}$, transparency, water temperature, $\mathrm{pH}$, nitrate, phosphate and silicate.

Surface water salinity was measured in the field by refractometer and cross-checked in the laboratory by argentometric method. Transparency was measured in the field by using a Secchi disc of $30 \mathrm{~cm}$ in diameter. Surface water temperature was measured by a Celsius thermometer and $\mathrm{pH}$ of the pond water was measured by a portable $\mathrm{pH}$ meter (sensitivity $= \pm 0.02$ ). BOD, DO, oil and grease, nitrate, phosphate and silicate were measured as per the procedure stated $[1,2]$.

The dissolved metal ( $\mathrm{Zn}, \mathrm{Cu}$ and $\mathrm{Pb}$ ) analysis of water samples through Atomic Absorption Spectrophotometer (AAS) were carried out as per Chakraborti et al. [3]. For microbial analysis of the coastal water in terms of Fecal Coliform load, the Most Probable Number (MPN) procedure by Multiple Fermentation Technique was followed as stated in 1998 [4] $20^{\text {th }}$ edition.

\section{Phase C: Water quality index evaluation}

For evaluating the water quality of the coastal water through $\mathrm{AHI}$ the following expression was adopted, which is a modification of Brown's index (1970):

$$
\sum_{\mathrm{i}=1}^{\mathrm{s}} \mathrm{W}_{i} \mathrm{X} \mathrm{q}_{i}
$$

where, $\mathrm{W}_{i}=$ weight of $\mathrm{i}^{\text {th }}$ parameter, $\mathrm{q}_{i}=$ quality of the $\mathrm{i}^{\text {th }}$ parameter (a number between 0 and 100). Depending on the importance of the parameter they are allotted a ranking value of 1 (highest) to 10 (lowest). To convert ratings into weights, a temporary weight of 1.0 was assigned to the parameter, which received the highest significance ratings (here salinity received the topmost score). All other temporary weights were obtained by dividing the highest ranking with each individual rating. Each temporary weight was then divided by the sum of all the temporary weights to arrive at the final weight of each parameter. The sum of the product of the individual final weight $\left(\mathrm{W}_{i}\right)$ and individual quality rating $\left(\mathrm{q}_{i}\right)$ was used (Tables 1-6).

Table 1: Significance, ratings and weights of the relevant parameters in connection to Coastal Water Quality determination.

\begin{tabular}{|c|c|c|c|}
\hline Parameter & Ranking & Temporary weight & Final weight $\mathrm{W}_{i}$ \\
\hline Salinity (\%) & 1.2 & 1.0000 & 0.2060 \\
\hline Fecal Coliform (No./100 ml) & 1.5 & 0.8000 & 0.1648 \\
\hline BOD (5-day) & 2.5 & 0.4800 & 0.0989 \\
\hline Dissolved oxygen (DO) (mg/l) & 2.9 & 0.4137 & 0.0852 \\
\hline Oil and grease(mg/l) & 3.1 & 0.3871 & 0.0797 \\
\hline Dissolved $\mathrm{Pb}(\mu \mathrm{g} / \mathrm{l})$ & 4.5 & 0.2667 & 0.0549 \\
\hline Dissolved $\mathrm{Cu}(\mu \mathrm{g} / \mathrm{l})$ & 4.7 & 0.2553 & 0.0526 \\
\hline Dissolved Zn $(\mu \mathrm{g} / \mathrm{l})$ & 4.9 & 0.2449 & 0.0504 \\
\hline Transparency $(\mathrm{cm})$ & 5.7 & 0.2105 & 0.0433 \\
\hline Temperature $\left({ }^{\circ} \mathrm{C}\right)$ & 6.5 & 0.1846 & 0.0380 \\
\hline $\mathrm{pH}$ & 7.1 & 0.1690 & 0.0348 \\
\hline $\mathrm{NO}_{3}(\mu \mathrm{g}$ at $/ \mathrm{l})$ & 7.9 & 0.1519 & 0.0313 \\
\hline $\mathrm{PO}_{4}(\mu \mathrm{g}$ at $/ \mathrm{l})$ & 8.1 & 0.1481 & 0.0305 \\
\hline \multirow[t]{2}{*}{$\mathrm{SiO}_{3}(\mu \mathrm{g}$ at $/ \mathrm{l})$} & 8.5 & 0.1412 & 0.0290 \\
\hline & & $\sum 4.8530$ & $\sum 0.9994$ \\
\hline
\end{tabular}


Table 2: Determination of Aquatic Health Index (AHI) for Canning (Stn 1).

\begin{tabular}{|c|c|c|c|c|c|}
\hline Parameter & Final weight $w_{i}$ & Measured Value & Optimum value Ref: * & Individual quality rating $q_{i}$ & $\mathbf{w}_{\mathrm{i}} \mathbf{q}_{\mathrm{i}}$ \\
\hline Salinity (\%) & 0.2060 & 24.45 & 25.00 & 98 & 20.188 \\
\hline Fecal Coliform (No./100 ml) & 0.1648 & 550 & 100 & 0 & 0 \\
\hline BOD (5-day) & 0.0989 & 6.2 & 3.0 & 0 & 0 \\
\hline Dissolved oxygen (DO) (mg/l) & 0.0852 & 5.12 & 5.00 & 98 & 8.3496 \\
\hline Oil and grease $(\mathrm{mg} / \mathrm{l})$ & 0.0797 & 2.9 & 0.1 & 0 & 0 \\
\hline Dissolved $\mathrm{Pb}(\mu \mathrm{g} / \mathrm{l})$ & 0.0549 & 34.57 & 10.00 & 0 & 0 \\
\hline Dissolved $\mathrm{Cu}(\mu \mathrm{g} / \mathrm{l})$ & 0.0526 & 152.47 & 50.00 & 0 & 0 \\
\hline Dissolved Zn $(\mu \mathrm{g} / \mathrm{l})$ & 0.0504 & 483.12 & 100.0 & 0 & 0 \\
\hline Transparency $(\mathrm{cm})$ & 0.0433 & 14.6 & 30.0 & 49 & 2.1217 \\
\hline Temperature (0C) & 0.0380 & 34.0 & 32.0 & 94 & 3.5720 \\
\hline $\mathrm{pH}$ & 0.0348 & 7.79 & 8.00 & 97 & 3.3756 \\
\hline $\mathrm{NO}_{3}(\mu \mathrm{g}$ at $/ \mathrm{l})$ & 0.0313 & 13.59 & 15.00 & 91 & 2.8483 \\
\hline $\mathrm{PO}_{4}(\mu \mathrm{g}$ at $/ \mathrm{l})$ & 0.0305 & 2.45 & 1.50 & 37 & 1.1285 \\
\hline \multirow[t]{2}{*}{$\mathrm{SiO}_{3}(\mu \mathrm{g}$ at $/ \mathrm{l})$} & 0.0290 & 107.67 & 80.0 & 65 & 1.8850 \\
\hline & & & & & $\sum w_{i} q_{i}=43.4687$ \\
\hline
\end{tabular}

Table 3: Determination of Aquatic Health Index (AHI) for Junput (Stn 2).

\begin{tabular}{|c|c|c|c|c|c|}
\hline Parameter & Final weight $w_{i}$ & Measured Value & Optimum value Ref: * & Individual quality rating $q_{i}$ & $w_{i} q_{i}$ \\
\hline Salinity (\%) & 0.2060 & 29.18 & 25.00 & 83 & 17.0980 \\
\hline $\begin{array}{l}\text { Fecal Coliform } \\
\text { (No./100 ml) }\end{array}$ & 0.1648 & 425 & 100 & 0 & 0 \\
\hline BOD (5-day) & 0.0989 & 5.8 & 3.0 & 7 & 0.6923 \\
\hline $\begin{array}{l}\text { Dissolved oxygen (DO) } \\
(\mathrm{mg} / \mathrm{l})\end{array}$ & 0.0852 & 4.11 & 5.00 & 82 & 6.9864 \\
\hline Oil and grease $(\mathrm{mg} / \mathrm{l})$ & 0.0797 & 3.1 & 0.1 & 0 & 0 \\
\hline Dissolved $\mathrm{Pb}(\mu \mathrm{g} / \mathrm{l})$ & 0.0549 & 18.46 & 10.00 & 15 & 0.8235 \\
\hline Dissolved Cu ( $\mu \mathrm{g} / \mathrm{l})$ & 0.0526 & 109.56 & 50.00 & 0 & 0 \\
\hline Dissolved Zn $(\mu \mathrm{g} / \mathrm{l})$ & 0.0504 & 348.69 & 100.0 & 0 & 0 \\
\hline Transparency $(\mathrm{cm})$ & 0.0433 & 15.9 & 30.0 & 47 & 2.0351 \\
\hline Temperature $\left({ }^{\circ} \mathrm{C}\right)$ & 0.0380 & 33.9 & 32.0 & 94 & 3.572 \\
\hline $\mathrm{pH}$ & 0.0348 & 8.34 & 8.00 & 96 & 3.3408 \\
\hline $\mathrm{NO}_{3}(\mu \mathrm{g}$ at $/ \mathrm{l})$ & 0.0313 & 13.15 & 15.00 & 88 & 2.7544 \\
\hline $\mathrm{PO}_{4}(\mu \mathrm{g}$ at $/ \mathrm{l})$ & 0.0305 & 1.71 & 1.50 & 86 & 2.6230 \\
\hline \multirow[t]{2}{*}{$\mathrm{SiO}_{3}(\mu \mathrm{g}$ at $/ \mathrm{l})$} & 0.0290 & 87.62 & 80.00 & 91 & 2.6390 \\
\hline & & & & & $\sum w_{i} q_{i}=41.3285$ \\
\hline
\end{tabular}


Table 4: Determination of Aquatic Health Index (AHI) for Sagar Island (Stn 3).

\begin{tabular}{|c|c|c|c|c|c|}
\hline Parameter & Final weight $w_{i}$ & Measured Value & Optimum value Ref: * & $\begin{array}{l}\text { Individual quality } \\
\text { rating } q_{i}\end{array}$ & $w_{i} q_{i}$ \\
\hline Salinity (\%) & 0.2060 & 28.11 & 25.00 & 88 & 18.1280 \\
\hline $\begin{array}{l}\text { Fecal Coliform } \\
\text { (No./100 ml) }\end{array}$ & 0.1648 & 170 & 100 & 30 & 4.944 \\
\hline BOD (5-day) & 0.0989 & 5.1 & 3.0 & 30 & 2.9670 \\
\hline $\begin{array}{l}\text { Dissolved oxygen (DO) } \\
(\mathrm{mg} / \mathrm{l})\end{array}$ & 0.0852 & 3.99 & 5.00 & 80 & 6.8160 \\
\hline Oil and grease (mg/l) & 0.0797 & 2.1 & 0.1 & 0 & 0 \\
\hline Dissolved $\mathrm{Pb}(\mu \mathrm{g} / \mathrm{l})$ & 0.0549 & 18.91 & 10.00 & 11 & 0.6039 \\
\hline Dissolved Cu ( $\mu \mathrm{g} / \mathrm{l})$ & 0.0526 & 68.36 & 50.00 & 63 & 3.3138 \\
\hline Dissolved Zn ( $\mu \mathrm{g} / \mathrm{l})$ & 0.0504 & 229.08 & 100.0 & 0 & 0 \\
\hline Transparency $(\mathrm{cm})$ & 0.0433 & 16.8 & 30.0 & 44 & 1.9052 \\
\hline Temperature $\left({ }^{\circ} \mathrm{C}\right)$ & 0.0380 & 33.9 & 32.0 & 94 & 3.5720 \\
\hline $\mathrm{pH}$ & 0.0348 & 8.33 & 8.00 & 96 & 3.3408 \\
\hline $\mathrm{NO}_{3}(\mu \mathrm{g}$ at $/ \mathrm{l})$ & 0.0313 & 14.15 & 15.00 & 94 & 2.9422 \\
\hline $\mathrm{PO}_{4}(\mu \mathrm{g}$ at $/ \mathrm{l})$ & 0.0305 & 1.75 & 1.50 & 84 & 2.5620 \\
\hline \multirow[t]{2}{*}{$\mathrm{SiO}_{3}(\mu \mathrm{g}$ at $/ \mathrm{l})$} & 0.0290 & 102.41 & 80.0 & 72 & 2.0880 \\
\hline & & & & & $\sum w_{i} q_{i}=50.5049$ \\
\hline
\end{tabular}

Table 5: Scorecard of the selected stations according to AHI.

\begin{tabular}{|c|c|c|}
\hline Station & $\mathbf{S} \mathbf{w}_{\mathbf{i}} \mathbf{q}_{\mathbf{i}}$ & Health Position \\
\hline Stn. 1 & 43.4687 & 2 \\
\hline Stn. 2 & 41.3285 & 3 \\
\hline Stn. 3 & 50.5049 & 1 \\
\hline
\end{tabular}

Table 6: Major Haldia Industries: Waste generation, treatment and disposal.

\begin{tabular}{|c|c|c|c|c|c|c|c|c|}
\hline \multirow[b]{2}{*}{$\begin{array}{l}\text { Name of the } \\
\text { Industry }\end{array}$} & \multirow[b]{2}{*}{$\begin{array}{c}\text { Size \& } \\
\text { Category }\end{array}$} & \multirow[b]{2}{*}{ Status } & \multirow[b]{2}{*}{$\begin{array}{c}\text { Water Use } \\
\left(\mathrm{m}^{3} / \mathrm{d}\right)\end{array}$} & \multicolumn{2}{|c|}{ Waste Generation } & \multicolumn{3}{|c|}{ Status of disposal of Waste Effluent } \\
\hline & & & & $\begin{array}{l}\text { Effluent } \\
\left(\mathrm{m}^{3} / \mathrm{d}\right)\end{array}$ & Solid $\left(\mathrm{m}^{3} / \mathrm{d}\right)$ & $\begin{array}{l}\text { Status of } \\
\text { Effluent }\end{array}$ & $\begin{array}{c}\text { Disposal } \\
\text { of Effluent } \\
\text { Discharged } \\
\text { in the Sea }\end{array}$ & Waste \\
\hline & & & & & & & $\begin{array}{l}\text { Direct/ } \\
\text { Indirect }\end{array}$ & Solid Waste \\
\hline $\begin{array}{c}\text { Shaw Wallace } \\
\text { \& Co. }\end{array}$ & $\begin{array}{c}\text { Large } \\
\text { Pesticides }\end{array}$ & Private & 265 & 50 & 0.007 & Treated & Indirect & NA \\
\hline $\begin{array}{l}\text { Hindustan } \\
\text { Liver Ltd. }\end{array}$ & $\begin{array}{c}\text { Large } \\
\text { Chemicals }\end{array}$ & Private & 3750 & 1065 & NA & Treated & Indirect & NA \\
\hline $\begin{array}{l}\text { Consolidated } \\
\text { Fibers \& } \\
\text { Synthetic } \\
\text { Chemicals Ltd. }\end{array}$ & Large Fiber & Private & 3185 & 2303 & 0.002 & Treated & Indirect & NA \\
\hline $\begin{array}{l}\text { Haldia Dock } \\
\text { Complex }\end{array}$ & Large Dock & Private & 2880 & 640 & 25 & Untreated & Indirect & NA \\
\hline IOC Ltd. & $\begin{array}{l}\text { Large Oil \& } \\
\text { Refinery }\end{array}$ & Private & 14650 & 13800 & NA & Treated & Indirect & NA \\
\hline $\begin{array}{l}\text { Chloride } \\
\text { Industries }\end{array}$ & $\begin{array}{c}\text { Large Lead } \\
\text { Battery }\end{array}$ & Private & 446 & 402 & 0.008 & Treated & Indirect & NA \\
\hline $\begin{array}{l}\text { HFC Ltd (Main } \\
\text { Plant fertilizer } \\
\text { not operating } \\
\text { since 1978) }\end{array}$ & $\begin{array}{l}\text { Large } \\
\text { Fertilizer }\end{array}$ & Private & 3400 & 3400 & NA & Partly Treated & Indirect & NA \\
\hline
\end{tabular}




\section{Result and Discussion}

The Ecologically Sensitive Zone (ESZ) may be defined as the zone which sustains endemic gene pool and restricts activities that pose adverse impact on the biodiversity and the physical environment of the zone. The basis of evaluating the ESZ is to understand the magnitude of human interference on natural system. Ion the present era the adverse impact on natural system has increased due to intense industrialization and rapid urbanization in the coastal zone. The mushrooming of shrimp farms and unplanned proliferation of tourism unit has increased the magnitude of deterioration of water quality in the coastal zone. It is in this context the environmental quality assessment, its monitoring and survey have received prime importance.

Water quality index (WQI) evaluation is an approach to understand the health of the aquatic system by considering all the parameters relevant for determining the ecologically sensitive zone in the coastal stretch. Evaluation of water quality index is a step to monitor the health of the aquatic ecosystem. The index has gained currency during the last three decades but the concept in its rudimentary form was first introduced more than 150 years ago - in 1848 - in Germany where presence or absence of certain organisms in water was used as indicator of the fitness or otherwise of a water source. Since then various European countries have developed and applied different systems to classify the quality of the waters within their regions. These water classification systems are usually of two types:

A. Those concerned with the amount of pollution present, and

B. Those concerned with living communities of microscopic or microscopic organisms.

Rather than assigning a numerical value to represent water quality, these classification systems categorized water bodies into one of several pollution classes or levels. By contrast, indices that use a numerical scale to represent gradations in water quality levels are a recent phenomenon, beginning with Horton's index in 1965.

In course of time, the National Sanitation Foundations Water Quality Index (NSFWQI) developed by Brown et al (1970), gained much importance, but the index does not recognize and incorporate specific water supply, agriculture, industry etc. Later on another Coastal Water Quality Index (CWQI) was established by Shyue et al (1996) to better understand the coastal water quality in Taiwan by using Delphi to select several parameters from Marien Water Quality Standard. But the parameters identified by them are $\mathrm{pH}$, DO, BOD, cyanide, $\mathrm{Cu}, \mathrm{Zn}, \mathrm{Pb}, \mathrm{Cd}$ and $\mathrm{Cr}$. These indexes also does not reflect parameters related to coastal and estuarine environment like salinity, silicate level, oil \& grease etc, which have great influence on regulating the health of those ecosystems. On this background, the present index is an addition of relevant parameters on the skeleton of Brown's index (1970). The Aquatic Health Index (AHI) in the present area of investigation is in the order Stn. 3 (Sagar Island, 50.5049) > Stn. 1 (Canning, 43.4687) > Stn. 2 (Junput, 41.3285). The order reflects the congenial environment at Sagar Island, which is at the confluence of the river Hugli and the Bay of Bengal. The presence of mangroves and the tidal flushing of the seawater (from Bay of Bengal) are the probable causes for environmental upgradation in this zone.

The Junput and Canning on the other hand are constantly under anthropogenic pressure due to presence of fish landing stations, markets, tourism and other human activities. It is become of human interference the coastal health undergoes deterioration and subsequently the value of aquatic health index gets reduced. In case of Canning the lower AHI value may be due to the proximity of the station to the highly urbanized and industrialized city of Kolkata, which regularly unload huge quantum of wastes of complex characters in the Kulti lock gate zone. But in case of Junput the lower AHI value may be attributed to excessive tourist load (as it is much nearer to the tourists spots of Digha and Shankarpur). In addition to this, the presence of fish landing stations at Junput is another prominent cause behind the lowering of the aquatic health index in this zone. The fishing vessels and trawlers contribute appreciable amount of $\mathrm{Zn}, \mathrm{Cu}$ and $\mathrm{Pb}$ (from the antifouling paints that are used for conditioning the vessels), oil and grease in the ambient aquatic phase. Absence of proper treatment facility in the landing stations resulted in enhancement of the value of BOD and microbial load.

The coastal and estuarine waters, being the cradle of several of finfish, shellfish, seaweeds of commercial importance, needs regular monitoring as a part of safe-guarding the ecosystem. The enumeration of Aquatic health index is a definite approach to pinpoint the magnitude of deterioration of the coastal zone on the basis of which proper planning can be done to keep the ecosystem intact and stable.

\section{References}

1. Strickland JDH, Parsons TR (1968) A Practical Handbook of Seawater Analysis. $2^{\text {nd }}$ Ed. In: Bulletin Fisheries Research Board of Canada, 167: 310.

2. APHA (American Public Health Association) (1995) Standard methods for the examination of water and waste water. $20^{\text {th }}$ edn, APHA, Washington DC, USA.

3. Chakraborty D, Adams F, Van Mol W, Irgolic JK (1987) Determination of trace metals in natural waters at nanogram per litre levels by electrothermal atomic absorption spectrometry after extraction with sodium diethyldithiocarbamate. In: Analytica Chemica Acta, 196: 23-31.

4. Mitra A (1998) Status of coastal pollution in West Bengal with special reference to heavy metals. Journal of Indian Ocean Studies 5(2): 135138. 


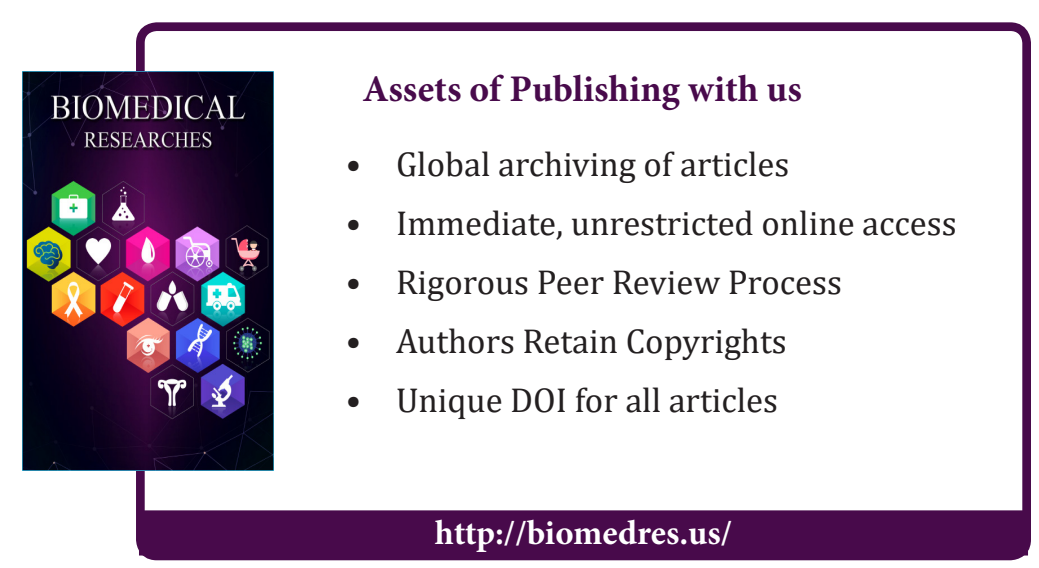

